This is an Accepted Manuscript of an article published by Taylor \& Francis in South African Journal on Human Rights on 2019, available online: http://www.tandfonline.com/ https://doi.org/10.1080/02587203.2019.1615351 
Social and economic rights to challenge violence against women examining and extending strategies

Beth Goldblatt

Faculty of Law, University of Technology Sydney, Australia

University of Technology Sydney PO Box 123 Broadway NSW 2007

Associate Professor, Faculty of Law, University of Technology Sydney, Australia;

Visiting Associate Professor, School of Law, University of the Witwatersrand, South Africa 


\title{
Social and economic rights to challenge violence against women - examining and extending strategies
}

\begin{abstract}
Violence against women and poverty are closely connected. Measures to address this violence must tackle the social and economic factors that contribute to gender inequality. Violence against women is now recognised as a human rights violation but this is often understood narrowly in relation to violations of civil and political rights. Social and economic rights offer rich possibilities to look beyond punitive responses to violence to more preventative measures that take account of systemic inequalities. This article examines some of the reasons why these rights have not been sufficiently developed and engaged. Drawing on the views and activities of South African public interest lawyers, researchers and activists working on violence against women as well as those involved with work on gendered poverty and service delivery, it suggests how social and economic rights might be further developed and applied in challenging this violence.
\end{abstract}

Keywords: violence against women; social and economic rights; gender; strategic litigation; poverty; public interest law

\section{Introduction}

In 2015, the High Court at Bombay ordered municipalities in the State of Maharashtra to develop schemes to construct public toilets for women. ${ }^{1}$ Women's safety and security were motivations for the decision alongside health concerns and the rights to dignity and equality. 'The Right to Pee', a Coalition of non-governmental organisations, referred to in the decision, had argued, along with other motivations, that the lack of

\footnotetext{
${ }^{1}$ Milun Saryajani Through Editor Geetali Vinayak Mandakini v Pune Municipal Commissioner, Pune Public Interest Litigation No. 98 of 2011 (2015) (High Court of Bombay decision) $<\underline{\text { https://indiankanoon.org/doc/3070943/> }}$
} 
public sanitation facilities expose women to sexual harassment and rape. ${ }^{2}$ The case demonstrates the links between social movement advocacy, public interest litigation, and progressive jurisprudence on gender and social and economic rights. The case highlights how a decision concerning social rights can respond to and have an impact on violence against women. ${ }^{3}$

Violence against women and poverty are closely related. ${ }^{4}$ Vulnerability to this violence may be aggravated in communities where services are inadequate: for example, where there is a lack of street lighting, where housing for women fleeing abuse is inadequate or absent, and where girls lack transport exposing them to attack on their way to school. Women involved in precarious work may be under more pressure to put up with harassment. In addition to protection measures and efforts to change the attitudes that enable this violence, measures to prevent violence aimed at addressing

\footnotetext{
${ }^{2}$ Hindustan Times 'Right to pee: Mumbai women want men to join their fight' (10 March 2016) $<$ http://www.hindustantimes.com/india/right-to-pee-mumbai-women-want-men-to-join-theirfight/story-MxpDVda6LTqLTWXhXucwPK.html>

${ }^{3}$ The celebrated decision in Vishaka $v$ State of Rajasthan [1997] SCC 241 (Supreme Court of India decision) is an example of an economic rights case relating to violence against women where sexual harassment was prohibited in certain workplaces.

${ }^{4}$ The term 'violence against women' is consciously employed here as the specific focus of this article because women, although not the only victims of gender-based violence, are the overwhelming majority. Men and boys can also be victims of domestic or sexual violence, and women can be perpetrators, while lesbian, gay, bisexual, transgender and intersex groups face particular forms of gender-based violence. Violence against women results from structural, unequal, gendered power relations that enable men to harm or control women through the use of force or its threat. The term should be taken to include girls.
} 
these service provision and decent employment gaps might contribute to eradicating or lessening violence. ${ }^{5}$

Violence against women is increasingly being understood as a violation of human rights, particularly traditional civil and political rights such as the rights to life, dignity, bodily integrity and autonomy. However, this is not universally accepted, for example, where rape in marriage is treated as an exception in some countries. ${ }^{6}$ Generations of feminists have engaged in struggles to win recognition of women as full and equal bearers of rights concerning their bodies. More recently, efforts to understand violence against women as an equality violation have targeted the international human rights terrain and in particular the Convention on the Elimination of All Forms of Discrimination against Women (CEDAW) that - surprisingly - does not refer to violence against women. ${ }^{7}$ While violence against women is now a recognised human rights concern, the rights frameworks do not always connect this issue sufficiently to

${ }^{5}$ The United Nations (UN) Committee on the Elimination of Discrimination against Women (CEDAW Committee) defines states parties' responsibilities with regard to ending violence against women as including measures for 'prevention, protection, prosecution, punishment and redress': CEDAW Committee 'General recommendation no. 35 on gender-based violence against women, updating general recommendation no. 19' (2017) UN Doc CEDAW/C/GC/35 para 28.

${ }^{6} \mathrm{M}$ Randall \& V Venkatesh 'Criminalizing sexual violence against women in intimate relationships: state obligations under human rights law' (2015) 109 American Journal of International Law Unbound 189.

${ }^{7}$ CEDAW (adopted 18 December 1979, entered into force 3 September 1981) 1249 UNTS 13. The CEDAW Committee has sought to remedy this gap through its general recommendations: CEDAW Committee 'General recommendation no. 19: violence against women' (1992) UN Doc A/47/38; CEDAW Committee (note 5 above). For a discussion of violence against women in international law see A Edwards Violence against Women under International Human Rights Law (2011); B Meyersfeld Domestic Violence and International Law (2010). 
social and economic rights. Although there is growing interest in this area, ${ }^{8}$ neither scholars nor lawyers or courts ${ }^{9}$ have adequately considered the relationship between violence against women and social and economic rights.

${ }^{8}$ The United Nations special rapporteur on violence against women, Yakin Ertürk, produced a
valuable report in 2009 addressing the political economy of violence against women. The report
pays close attention to social and economic rights: UN Human Rights Council (UNHRC) 'Report of the special rapporteur on violence against women, its causes and consequences, Yakin Ertürk' (2009) UN Doc A/HRC/11/6. See also F Raday \& S Oksenberg 'The impact of violence against women on women's economic and social life' Background paper for the working group on the issue of discrimination against women in law and in practice to inform the thematic report: UNHRC 'Report of the working group on the issue of discrimination against women in law and in practice: thematic report' (2014) UN Doc A/HRC/26/39; and B Goldblatt 'Violence against women and social and economic rights: deepening the connections' in $\mathrm{S}$ Harris-Rimmer \& K Ogg (eds) Research Handbook on The Future of Feminist Engagement with International Law (forthcoming 2019). In the African context, see S Dauer \& M Gomez 'Violence against women and economic, social and cultural rights in Africa' (2006) 7 Human Rights Review 49; E Bonthuys 'Domestic violence and gendered socio-economic rights: an agenda for research and activism?' (2014) 30 South African Journal on Human Rights 111; L Gerntholtz \& J MacLeod 'Gender and socio-economic rights' in M Langford, B Cousins, J Dugard \& T Madlingozi (eds) Socio-Economic Rights in South Africa: Symbols or Substance? (2013) 365. In the Mexican context see, AM Sánchez Rodríguez 'Contesting neoliberalism: bringing in economic and social rights to end violence against women in Mexico' in G MacNaughton \& DF Frey (eds) Economic and Social Rights in a Neoliberal World (2018) 173.

9 There is a growing body of literature on gender and social and economic rights in constitutional and international law that sometimes refers to violence against women, but a deeper consideration is still needed. See, for example, C Chinkin 'Gender and economic, social and cultural rights' in E Reidel, G Giacca \& C Golay (eds) Economic, Social, and Cultural Rights in International Law (2014) 134; S Fredman 'Engendering social and economic rights' in B Goldblatt \& K McLean (eds) Women's Social and Economic Rights: Developments in South Africa (2011) 4; D Otto 'Gender comment: why does the UN Committee on Economic, Social and Cultural Rights need a general comment on women?' (2002) 14 Canadian Journal of Women and the Law 1; B Goldblatt 'Constitutional approaches to gender and social and economic rights' in H Irving (ed) Constitutions and Gender (2017) 482. 
This article, in exploring ways of improving the mobilisation of social and economic rights to tackle the intractable problem of violence against women, examines some of the reasons why these rights have not been sufficiently developed and engaged. It does this mindful of enduring questions about the potential for social and economic rights to achieve distributive change and more broadly about the utility of human rights and even the law itself in challenging social and economic inequality. ${ }^{10}$ These debates coincide with an ongoing examination within feminism about the usefulness and dangers of engaging with law and rights, particularly in relation to violence. ${ }^{11}$

The article discusses the use of social and economic rights to address violence against women in the South African context. It considers the views of South African public interest lawyers, researchers and activists working on violence against women as well as those involved with work on gendered poverty and issues of service delivery. In a country where legal and rights-based responses to violence against women have focused primarily on policing and justice reform with limited tangible impact, the article

\footnotetext{
${ }^{10}$ See UNHRC 'Report of the special rapporteur on extreme poverty and human rights' (2016) UN Doc $\mathrm{A} / \mathrm{HRC} / 32 / 31$ for an argument for greater recognition, institutionalisation and accountability of social and economic rights at the national and international levels to address poverty and economic inequality.

${ }^{11}$ In relation to international law see J Halley Split Decisions: How and Why to Take a Break from Feminism (2006); H Charlesworth 'Talking to ourselves? Feminist scholarship in international law' in S Kouvo \& Z Pearson (eds) Feminist Perspectives on Contemporary International Law: Between Resistance and Compliance? (2011) 17. In relation to human rights see SE Merry Human Rights and Gender Violence (2006); N Lacey 'Feminist legal theory and the rights of women' in K Knop (ed) Gender and Human Rights (2004) 13; EA Schneider 'The dialectic of rights and politics: perspectives from the women's movement' (1986) 61 New York University Law Review 589. In relation to using the law more generally (and in relation to violence against women in particular), see the foundational text by $\mathrm{C}$ Smart, Feminism and the Power of Law (1989).
} 
questions whether a different approach might contribute to achieving greater safety for South African women. The lessons from this context may have application for other countries with constitutional or legislated social and economic rights and help to strengthen international law approaches to violence against women.

The article begins by examining how social and economic rights are implicated in issues of violence facing women in poverty (Section 2). It considers explanations as to why these rights have not been fully explored or mobilised in the South African context (Section 3). It draws on some examples of creative litigation, advocacy and other strategies in South Africa that make use of these rights in suggesting how such rights might be further developed and applied in challenging this systemic harm (Section 4). Lastly, it suggests some areas for further enquiry (Section 5).

\section{Poverty, violence against women, and social and economic rights}

Violence against women is experienced across class, race, culture and religion. It affects women at all levels of society regardless of socio-economic status or access to political power. There is, however, a close relationship between poverty and violence that affects women with limited access to resources in specific and significant ways. ${ }^{12}$ While poverty is not necessarily a cause of violence, it can exacerbate women's vulnerability to violence, have an impact on their ability to access necessary response and support mechanisms, and diminish their mitigation capacity. The following are some of the dimensions of the interrelationship between violence and poverty. ${ }^{13}$ Violence can deepen poverty by forcing women out of their homes or workplaces, necessitating

\footnotetext{
${ }^{12}$ For a discussion of the economic contributors to violence against women see $\mathrm{J}$ True The Political Economy of Violence Against Women (2012); UNHRC (2009) (note 8 above).

${ }^{13}$ The dimensions that follow are drawn from B Goldblatt (2019) (note 8 above).
} 
greater expenditure on accommodation, health and transport, and reducing their livelihoods. Violence and fear of its occurrence can prevent women from accessing healthcare, education and other services, leading to reduced life chances. Violence can take the form of control of women's access to finances and resources ('economic violence' as a form of domestic violence). It could also lead to mental and physical ill health and disability, which can have an impact on women's access to income, employment and other forms of participation in society. Poverty can prevent women from escaping violent situations in the home or in the community. It can also push women into unsafe work environments and public spaces. ${ }^{14}$ The reduction or removal of services, such as cutbacks on welfare or public housing, can expose women to violence. ${ }^{15}$ Many of these issues are exacerbated in the context of war, disaster and other forms of social disruption. ${ }^{16}$ The interrelationship between poverty and violence creates a range of barriers to women's social, economic and civic/political participation.

Social and economic rights offer to address some of the underlying conditions that expose women to violence thus potentially performing a preventative function. This is valuable since many of the traditional policing and justice system responses to violence are seen as reactive or even harmful and as inadequate in addressing the structural nature of this violence. Writing about the Indian context, Ratna Kapur suggests that the use of rights and law in response to violence against women leads to

\footnotetext{
${ }^{14}$ Raday \& Oksenberg (note 8 above).

15 R Sander-McDonagh, L Neville \& S Nolas 'From pillar to post: understanding the victimisation of women and children who experience domestic violence in an age of austerity' (2016) 112 Feminist Review 60.

${ }^{16}$ See D Sankey 'Gendered experiences of subsistence harms: a possible contribution to feminist discourse on gendered harm?' (2015) 24 Social \& Legal Studies 25 for a discussion of the idea of socio-economic violence in conflict situations and its gendered dimensions.
} 
increased surveillance of women and control of their bodies and movement through a 'sexual security regime' that promotes state interests in supporting the market. ${ }^{17} \mathrm{~A}$ focus on the economic causes of violence shifts attention from this security agenda and requires an examination of the political and economic forces at the global and local levels that place women in positions of deepening vulnerability and harm. ${ }^{18}$ By using rights to require adequate resourcing of communities, the attention moves from responses that may be overly concerned with protection of women to more empowering solutions that recognise the barriers to women's agency and participation. ${ }^{19}$ This does not mean that protection has no place - adequate resourcing of police and courts is a key demand of the movement to end this violence. Social and economic rights can contribute to making communities safer through improved transport, street lighting and so on. But more fundamentally, guaranteeing women decent education, jobs and housing can improve their chances of avoiding dependence on violent men. This does not reduce the need to confront attitudinal factors that underlie patriarchal practices. Addressing violence against women requires a sophisticated and multi-faceted approach within which social and economic rights have one - arguably important - role to play.

\footnotetext{
${ }^{17} \mathrm{R}$ Kapur 'Gender, sovereignty and the rise of a sexual security regime in international law and postcolonial India' (2013) 14 Melbourne Journal of International Law 317.

${ }^{18}$ See Sánchez Rodríguez (note 8 above) for a discussion of neoliberalism and its impact on violence against women.

${ }^{19}$ See M Nussbaum 'Women's progress and women's human rights' (2016) 38 Human Rights Quarterly 589, 610, where it is argued that changing women's economic position is more likely to address issues such as domestic abuse than direct interventions in the home, which are often resisted.
} 
Social and economic rights should be developed in close interaction with equality rights if they are to address gender discrimination, disadvantage and violence. ${ }^{20}$ This is because poverty is linked to economic inequality that is, in turn, shaped by gender. Some aspects of poverty are common to men and women, for example where water, electricity and healthcare are inadequate. This poverty, though seemingly equal in its scope, is experienced differently by men and women due to gender disadvantage. ${ }^{21}$ For example, women may have greater responsibilities for collecting water and gathering fuel than men due to sexual divisions of labour, cultural expectations and stereotypes. In addition, women may be discriminated against because they are the victims of violence such as by landlords who evict them or by employers who dismiss them. Discrimination can be intersectional leading certain groups of poor women to experience greater exposure to violence such as women with disabilities, migrant and refugee women, girls and older women. ${ }^{22}$ Responding to violence against women requires measures to address poverty and the structural basis of economic inequality in its general manifestation as well as the causes of gendered poverty and unequal access to resources and opportunities. ${ }^{23}$ This requires a substantive equality approach in combination with social and economic rights to address 'pre-existing patterns of crosscutting structural subordination, gender hierarchies, systemic marginalization and

\footnotetext{
${ }^{20}$ Fredman (note 9 above); G Brodsky \& S Day 'Beyond the social and economic rights debate: Substantive equality speaks to poverty' (2002) 14 Canadian Journal of Women and the Law 185; Goldblatt (2019) (note 8 above).

${ }^{21}$ S Fredman 'Women and poverty: a human rights approach' (2016) 24 African Journal of International and Comparative Law 494.

${ }^{22}$ B Goldblatt 'Intersectionality in international anti-discrimination law: addressing poverty in its complexity’ (2015) 21 Australian Journal of Human Rights 47.

${ }^{23}$ B Agarwal \& P Panda 'Toward freedom from domestic violence: The neglected obvious' (2007) 8 Journal of Human Development 359.
} 
structural inequalities that may be at the root cause of the violence that women experience'. ${ }^{24}$

\section{Challenges in using social and economic rights to address violence against women in South Africa}

The close relationship between poverty and violence against women suggests that social and economic rights litigation is an obvious strategic vehicle for public interest lawyers concerned with addressing both of these issues. Yet such litigation appears quite limited internationally. ${ }^{25}$ While social and economic rights are increasingly being used to argue for greater resources for women and to address gender disadvantage, few of the cases of this type concern violence against women. ${ }^{26}$ This article explores some of the reasons arising in the South African context that might explain the limited use of these rights in relation to violence. South Africa is a useful case study because of its strong constitutional social and economic rights, the record of the Constitutional Court over more than twenty years in developing its social and economic rights jurisprudence, and its sophisticated public interest law sector. It is also studied because of the challenges that face the country in addressing an epidemic of violence against women, both

${ }^{24}$ UNHRC 'Report of the special rapporteur on violence against women, its causes and consequences, Rashida Manjoo' (2013) UN Doc A/HRC/23/49, 21.

${ }^{25}$ However, note two recent United Kingdom cases concerning housing and social protection rights of women affected by violence: Yemshaw v London Borough of Hounslow [2009] EWCA Civ 1543, [2011] UKSC 3; The Queen on the application of Sheila Winder, Lisa Marie Dowen and Sarah Hampton v Sandwell Metropolitan Borough Council [2014] EWHC 2617 (Admin).

${ }^{26}$ Goldblatt (note 8 above). 
gender-based violence in and outside of the home, and sexual violence. ${ }^{27}$ Rape has been described by the Constitutional Court as 'an inescapable and seemingly ever-present reality and scourge on the nation and the collective conscience of the people of South Africa' ${ }^{28}$

\subsection{Jurisprudence}

The Constitutional Court has provided decisions in at least ten cases concerning violence against women over the last two decades. These have dealt with criminal law and procedure, domestic violence legislation and common law issues related to civil liability for state employees. ${ }^{29}$ None of these cases has referred to any of the constitutional social and economic rights. At the same time, the social and economic rights jurisprudence of the Court has given little attention to violence against women.

Social and economic rights claims in some of the leading South African cases have been largely silent on the gender dimensions and, more particularly, on the gendered violence dimensions of the issues being litigated. The Government of the Republic of South Africa v Grootboom case, ${ }^{30}$ where the first named applicant was a homeless woman living with her sister's family as well as her own is notable in this regard. The judgment did not elaborate on the background of Irene Grootboom and the

\footnotetext{
${ }^{27}$ PD Gqola Rape: A South African Nightmare (2015). Also see Gerntholtz \& MacLeod (note 8 above) 369-371 for a discussion of how this violence impacts on the social and economic rights of women and girls.

${ }^{28}$ Ndlovu $v$ The State 2017 (10) BCLR 1286 (CC) para 53.

${ }^{29}$ For an assessment of this jurisprudence see B Goldblatt 'Violence against women in South Africa: constitutional responses and opportunities' in R Dixon \& T Roux (eds) Constitutional Triumphs, Constitutional Disappointments a Critical Assessment of the 1996 South African Constitution's Local and International Influence (2018) 141.

${ }^{30}$ Government of the Republic of South Africa v Grootboom 2001 (1) SA 46 (CC).
} 
life circumstances that led to her dire situation, along with that of other members of her community, so we do not know if violence contributed to her plight. The Court in this case viewed the poor as a largely undifferentiated group although it did give attention to the specific rights of children. ${ }^{31}$ The Court made reference to crisis situations such as natural emergencies that render people homeless but failed to note violence against women as a common cause of homelessness. Had the gendered context of the housing crisis been central to argument in the case, this may have emerged more explicitly in the decision, even if it would not have led the Court to a different result. While the case is rightfully celebrated, including for its alignment of social rights with a substantive notion of equality, ${ }^{32}$ it illustrates how the specific dimensions of gendered poverty can remain submerged within a broader understanding of economic inequality. This presents challenges to public interest litigators to foreground the needs of women in their choice of cases or in the evidence they present to courts.

Similarly, in the case of Mazibuko $v$ City of Johannesburg concerning provision of water services, four of the five applicants were women facing poverty. ${ }^{33}$ While issues of race discrimination were considered in the judgment, gender issues affecting women's specific circumstances with regard to water were not covered. The applicants had drawn attention to the gendered impacts of limited access to water, for example in relation to their responsibilities for washing nappies, looking after ill family members

\footnotetext{
${ }^{31} \mathrm{~K}$ McLean \& L Chenwi “"A woman's home is her castle?" Poor women and housing inadequacy in South Africa' (2009) 25 South African Journal on Human Rights 517.

${ }^{32} \mathrm{P}$ de Vos 'Grootboom, the right of access to housing and substantive equality as contextual fairness' (2001) 17 South African Journal on Human Rights 258.

${ }^{33}$ Mazibuko v City of Johannesburg 2010 (4) SA 1 (CC).
} 
and doing laundry. ${ }^{34}$ This was recognised in the earlier decision of the high court, which noted the discriminatory impact of inadequate access to water on women responsible for domestic chores; however, the Constitutional Court decision overlooked this dimension. ${ }^{35}$ Like Grootboom, the case demonstrates that the specific needs of women within the broader population facing poverty require carefully tailored litigation strategies if their circumstances are to be recognised and addressed.

The Minister of Health $v$ Treatment Action Campaign (No. 2) (TAC) case $^{36}$ concerning antiretroviral treatment in mother-to-child transmission of HIV is an example not just of silence on the gender issues but of an approach that potentially undermines women's rights. Cathi Albertyn argued that '[i]f women are granted access to such treatment solely out of a need to "save" their children, they tend to be viewed as mere vessels of reproduction rather than as rights-bearing citizens' ${ }^{37}$ She laid the blame for this failure not only with the court and the groups that brought the case but also with the women's groups who were unable to turn the political and legal campaign around HIV/AIDS into a feminist issue. ${ }^{38}$ While the case concerned women's bodies, attention to the close link between violence against women and HIV infection was not a focus. ${ }^{39}$

${ }^{34}$ J Dugard \& N Mohlakoana 'More work for women: a rights-based analysis of women's access to basic services in South Africa' (2009) 25 South African Journal on Human Rights $546,565$.

${ }^{35}$ Mazibuko v City of Johannesburg 2008 (4) All SA 471 (W) para 159.

${ }^{36}$ Minister of Health $v$ Treatment Action Campaign (No. 2) 2002 (5) SA 721 (CC).

${ }^{37} \mathrm{C}$ Albertyn 'Gendered transformation in South African jurisprudence: poor women and the constitutional court' (2011) 22 Stellenbosch Law Review 591, 599.

${ }^{38} \mathrm{C}$ Albertyn 'Contesting democracy: HIV/AIDS and the achievement of gender equality in South Africa' (2003) 29 Feminist Studies 595, 610.

${ }^{39}$ For a discussion of the politics around this gap see C Albertyn \& S Meer 'Citizens or mothers? The marginalisation of women's reproductive rights in the struggle for access to 
A case concerning the rights of pregnant school students to continue their studies is a more positive example of the Constitutional Court acknowledging sex discrimination alongside the right to education, although the judgment did not comment on the fact that coercive sex, including by fellow students and teachers, is one of the causes of teenage pregnancy. ${ }^{40}$ The broader context of gendered violence and its relationship to reproduction would have made the equality arguments more compelling. This case review demonstrates that social rights cases brought to the Constitutional Court have not adequately reflected the gender and - more specifically - the violence against women backdrop to the poverty that the cases were aimed at addressing. Bringing these issues to the fore might result in more targeted orders and a more nuanced jurisprudence and accompanying messaging that contributes to the political impact of such cases.

\subsection{Methodology}

The article now considers possible explanations for the limited use of social and economic rights in cases concerning violence against women and the absence of a focus on violence against women in cases concerning social and economic rights. The views of public interest litigators, activists and researchers working on violence against women and/or social and economic rights were canvassed to inform the ideas developed in this article. These related to a range of activities by public interest law groups including litigation, training, research and advocacy. The author, together with a fellow

health care for HIV-positive pregnant women in South Africa' in M Mukhopadhyay \& S Meer (eds) Gender, Rights and Development (2008) 27.

${ }^{40}$ Head of Department, Department of Education, Free State Province v Welkom High School; Head of Department, Department of Education, Free State Province v Harmony High School and Another 2014 (2) SA 228 (CC). 
women's rights scholar, ${ }^{41}$ worked with a leading public interest law organisation ${ }^{42}$ to select participants that were representative of the public interest law sector in South Africa. This involved approaching individuals and organisations nationally with a record of work on these issues. Twenty-one people agreed to participate in the study and attend a workshop. ${ }^{43}$ Participants included representatives of a social justice movement, a social justice campaign, university-based research centres, independent public interest law organisations, a donor organisation and academics. ${ }^{44}$ The comments the participants provided were individual opinions rather than representative views of their organisations. While these (anonymised) comments offer some indication of the views across the sector, they should not be seen as providing a fully representative picture of the sector. Rather, they offer some indication of the perceptions and understandings of key players that are used to inform the ideas developed in this article. Their comments assist in explaining the contributing causes of the under-use of social and economic rights in relation to violence against women and inform the development of approaches to address this.

\subsection{Explanatory factors}

The article suggests that the failure to link the issues of violence against women and social and economic rights can be attributed, at least in part, to the following: organisational challenges and the capacity of actors in the sector, obstacles related to

\footnotetext{
${ }^{41}$ Elsje Bonthuys, University of the Witwatersrand.

${ }^{42}$ The Centre for Applied Legal Studies (CALS) based at the University of the Witwatersrand.

${ }^{43}$ The workshop was held at the University of the Witwatersrand on 19 June 2017. Research ethics approval was provided for this research by the University of Technology Sydney Human Research Ethics Committee (UTS HREC REF NO. ETH17-1267).

${ }^{44}$ Certain key actors were unable to participate due to competing commitments on the day.
} 
choice and design of strategies, and concerns with the limits of law and the willingness or ability of the state to deliver change.

\subsection{Organisational issues}

There is a long history of feminist legal work on violence against women predating the end of apartheid. Some of the older public interest law organisations - the Legal Resources Centre, Lawyers for Human Rights (LHR) and the Centre for Applied Legal Studies (CALS) - have included work on violence against women within their broader focus on gender rights following decades of feminist efforts. ${ }^{45}$ Public interest law organisations, such as the Women's Legal Centre and Sonke Gender Justice, were established with gender equality as a central purpose, which has included a focus on violence, while Tshwaranang Legal Advocacy Centre and Lawyers Against Abuse were established with the specific purpose of addressing violence against women. The Centre for Child Law has been a key player on children's rights, including the rights of girls, and has worked on issues of gender-based violence. Centres at the University of Cape Town and the University of the Western Cape have actively been researching gender and social and economic rights. More recently, social and economic rights organisations such as Section 27 and the Socio-Economic Rights Institute have emerged, as have new member-based organisations working on social justice, such as the Social Justice Coalition, Equal Education and Ndifuna Ukwazi, and others on regional human rights on the African continent such as the Southern Africa Litigation Centre and the Initiative

\footnotetext{
${ }^{45}$ Newer public interest law organisations such as ProBono. Org have also covered this in their work.
} 
for Strategic Litigation in Africa. ${ }^{46}$ These organisations collaborate closely with other organisations, alliances and individuals working on women's rights and social justice issues.

The challenge for those involved in the violence sector has been to think beyond the criminal justice focus and look for opportunities to engage social and economic rights. This has not always proved easy for these actors as donors often draw sectoral lines through history and tradition, and because the law itself reinforces these demarcations.

For those working on social and economic rights, feminist issues are not always at the forefront of their organisational and strategic approaches. One of the workshop participants observed that not all the members of social and economic rights organisations are feminists or see the value of, or need for, feminist arguments in these cases. Another participant, recognising this shortcoming, argued for public interest law organisations to develop a 'pro-poor feminist approach to litigation'. These comments suggest two possibilities: that feminist arguments are not being advanced in the organisations or that feminist arguments are being rejected or ignored. Turning to the first possibility, feminist arguments may not be advanced due to fear of ridicule, an unreceptive organisational culture, or the lack of a critical mass of colleagues to support such arguments. The recent inquiry into sexual harassment in one of the social justice organisations indicates that progressive organisations, as elsewhere in society, are not immune to sexism. Zackie Achmat of Equal Education is quoted as saying, 'It is clear to me that we have work to do and must continue to do work already underway to address

\footnotetext{
${ }^{46}$ For a recent mapping of the sector see J Brickhill 'Introduction: the past, present, and promise of public interest litigation in South Africa' in J Brickhill (ed) Public Interest Litigation in South Africa (2018) 4, 16-36.
} 
sexual violence, power and patriarchy in our campaigns, organisations and movements'. ${ }^{47}$ Feminist arguments may be ignored because they are seen as divisive, ancillary to the central concerns of the organisation or something to be dealt with separately by women. The TAC case is an illustration of feminist arguments being pushed aside because they were viewed as an impediment to the litigation strategy. Cathi Albertyn and Shamim Meer document feminist lawyers' decision to work with the Reproductive Rights Alliance as an amicus curiae in the case because they were unable to advance their views within the main case; the Alliance was then asked to withdraw its amicus application to save time for the main case. ${ }^{48}$ Litigation strategies are undoubtedly shaped by lawyers' evaluation of the public's and the courts' receptiveness to their arguments. The inability of feminist lawyers to convince others in their organisations or teams of their arguments speaks also to the challenges of marshalling such arguments in an unsympathetic or even hostile context.

Violence against women may not be central to social and economic rights cases because of the way in which litigation strategies are developed. In some instances, research and consultation in communities informs the choice of issues while in others client interviews lead to the identification of legal problems. The questions that are asked in research and interviews, if not informed by feminist understandings, may not produce information pointing to intersections between violence against women and social rights deprivations. Similarly, if information gathered is not analysed using a

\footnotetext{
${ }^{47} \mathrm{C}$ Pitt 'Sexual misconduct cover-up allegations at Equal Education "left an indelible scar" $\begin{array}{lllll}\text { Zackie } & \text { Achmat' } & (29 & \text { November } & \text { 2018 }\end{array} \quad$ News24 $<$ https://www.news24.com/SouthAfrica/News/sexual-misconduct-cover-up-allegations-atequal-education-left-an-indelible-scar-zackie-achmat-20181129>
}

${ }^{48}$ Albertyn \& Meer (note 39 above) 40-1. 
feminist lens, the conclusions drawn my also fail to make these links. Where communities are consulted and the voices of men are privileged as being representative, these links may go unnoticed. A workshop participant noted that women in these communities are sometimes pushed to the 'side-lines of mobilisation and organisation strategies'.

A further organisational factor that may explain the lack of synergies between issues of violence against women and social and economic rights relates to lack of collaboration between relevant organisations. This may be partly linked to funding which contributes to keeping women's rights work somewhat separate from social and economic rights work. A donor organisation present at the workshop mentioned the historical focus areas within the women's movement in South Africa that have solidified over time and acknowledged its own role in not working in a more integrated way with partners that would encourage links around issues of gender and class and economic empowerment of women facing violence. Competition within the sector over scarce donor funding may also restrict collaboration. ${ }^{49}$ The funding challenges facing the public interest law sector are significant. ${ }^{50}$

Some public interest lawyers and researchers working on violence against women may not yet have turned their attention sufficiently to the feminist possibilities of social and economic rights for reasons of capacity, and not just due to resource

\footnotetext{
49 A participant voiced a concern that donor funding was going into strategic litigation rather than work on front-line legal services on violence against women (state and non-profit), which were described as inadequate.

${ }^{50}$ S Budlender, G Marcus \& N Ferreira Public Interest Litigation and Social Change in South Africa: Strategies, Tactics and Lessons (2014) 10-12, hereafter 'the Atlantic Philanthropies Report'.
} 
constraints. ${ }^{51}$ Some lawyers see social and economic rights as an area of specialisation in which they are not equipped. For those working on social and economic rights, the opposite issue of capacity arises in relation to law on gender and violence. One of the workshop participants asked:

\begin{abstract}
So, when we look more at the strategies in the cases that we are litigating, how are we bringing in the gender arguments and perhaps more frankly, do we have the capacity as litigators? Is this something that we are able to do? Do we have enough knowledge on how to bring those issues in and how to basically identify ourselves as feminist litigators and make it seen through our work?
\end{abstract}

The systemic links between poverty and violence against women are, however, obvious to activists working in poor communities. They appreciate the value of making claims for social and economic rights that might be more far-reaching than current responses to the brutalities facing women and girls at the hands of violent men. A social movement campaigner who works in the informal settlements of the Western Cape explained:

So, I understand why someone says: 'I am not for litigation. I don't want to go stand outside court singing Senzenina'. ${ }^{52}$ Because that's what we do because she was raped and murdered. But I want to then speak about the fact that why is there no proper transport system? Why did she have to be killed on her way to work? I would rather want to go to court and argue for (why) she was taken on her way to school and then murdered. So, if we solve those economic issues then we are directly maybe speaking to the issue around gender violence.

There may, however, be real problems of capacity for public interest lawyers and

\footnotetext{
${ }^{51}$ However, issues of capacity and resources are closely connected. Budlender et al ibid 12-13 notes the challenges of recruiting and retaining skilled public interest lawyers.

${ }^{52}$ A song meaning 'What have we done?' made famous in anti-apartheid protests and sung at funerals and demonstrations such as outside court buildings where men stand trial for murdering women.
} 
activists trying to make the conceptual and legal links between social and economic rights, gender equality and violence against women. These links are sometimes subtle and require creativity, boundary-breaking legal approaches and nuanced strategies. Public interest lawyers will by default follow gender-neutral social and economic rights strategies if feminist arguments are not developed, advanced and in, some cases, fought for. This requires individual and organisational capacity, resources and tenacity as well as organisations' and legal teams' receptiveness to such arguments.

\subsection{Constraints of legal categories}

Feminist legal theorists have noted that law forces lived experience into ill-fitting categories and that women struggle to align their lives with these categories since the default subject of law is male, often white, and privileged. ${ }^{53}$ This creates a range of barriers for women encountering violence in approaching the law. The law usually requires participants to pursue legal claims within rigid legal fields. Lawyers must decide if their client is experiencing a problem in areas such as 'criminal law', 'labour law', administrative law or 'family law' in order to pursue appropriate remedies. Each of these fields requires specialised skills and knowledge and lawyers are not always equipped to move between areas of legal practice. A participant explained that violence against women legal services in South Africa tend not to offer holistic services that link clients to lawyers skilled in immigration, labour, education and so on. This prevents them from getting the complete assistance that the complexities of their situation often require.

\footnotetext{
${ }^{53}$ K O’Donovan Sexual Divisions in Law (1985); R Graycar \& J Morgan The Hidden Gender of Law (2002).
} 
Feminist legal scholars and practitioners have worked hard to expand legal boundaries and create new legal categories such as domestic violence and sexual harassment. ${ }^{54}$ While this is a major achievement, legal work on violence against women has effectively become a field itself requiring experts focussed on advising clients to navigate the complexities of the law while avoiding secondary trauma. Without such support, and often even with it, violence complainants struggle with the challenges of fitting their experiences into the legal 'boxes' with which they are presented. Law reform and public interest litigation in this field have aimed to improve the legal frameworks, judicial approaches and policing practices in South Africa. ${ }^{55}$ This has required significant effort in a context where implementation of new law and policy is often inadequately resourced and poorly executed. It is unsurprising that legal advocates working on violence against women have had little opportunity to turn their attention to other legal avenues such as social and economic rights. At the same time, lawyers trying to raise gender issues in social and economic rights cases have not worked sufficiently closely with lawyers dealing with violence against women because these have been seen as separate areas of law.

Courts also struggle to step outside of categorical thinking. Even where issues of women's social and economic rights arise, it is difficult to get judges to consider both

\footnotetext{
${ }^{54}$ EA Schneider \& C Hanna 'The development of domestic violence as a field: honoring Clare Dalton' (2012) 20 Journal of Law \& Policy 343; Schneider (note 10 above); CA MacKinnon Sexual Harassment of Working Women: A Case of Sex Discrimination (1979).

${ }^{55}$ L Artz \& D Smythe 'Feminism vs. the state? A decade of sexual offences law reform in South Africa' (2007) 74 Agenda 6; C Albertyn, L Artz, H Combrinck, S Mills \& L Wolhuter 'Women's freedom and security of the person' in E Bonthuys \& C Albertyn (eds) Gender, Law and Justice (2007) 295; D Smythe Rape Unresolved: Policing Sexual Offences in South Africa (2015).
} 
class and gender issues as they tend to avoid complex problems that traverse categories. Albertyn has noted that:

The emphasis on poverty at the expense of other forms of inequality and exclusion, or on singular rather than intersectional forms of discrimination, is commonplace in political and legal discourse. Single issues simplify the complexities of life, making them easier to describe and adjudicate. ${ }^{56}$

Bonita Meyersfeld and Nomonde Nyembe have argued similarly that, 'the Constitutional Court has seldom demonstrated sensitivity to, or an understanding of, the multiplicity of ways in which black women in particular experience discrimination in post-apartheid South Africa', ${ }^{57}$ even where women's rights interventions raise intersectional gender issues.

Linking violence against women to poverty and to a range of social and economic (and other) rights in examining diverse areas of law demands sophistication, agile thinking and a willingness to step outside of the comfort of familiar legal approaches. Creative and lateral responses to the challenging interaction between violence against women and poverty may result in more effective legal strategies drawing on social and economic rights.

\subsection{Despondency with rights, law and the state}

A final challenge in aligning legal work on violence against women with social and economic rights arises from the weariness being felt in the sector. Years of hard work

\footnotetext{
${ }^{56}$ Albertyn (note 37 above) 610.

${ }^{57}$ B Meyersfeld \& N Nyembe 'Gender and public interest litigation in post-apartheid South Africa: Have "systematic motifs of discrimination" been addressed?' in J Brickhill (ed) Public Interest Litigation in South Africa (2018) 185, 186. However, they note that minority judgments of the court have been more open to an intersectional and gender-based approach.
} 
on law reform and implementation of new laws come up against consistently poor rape conviction rates, ${ }^{58}$ ongoing policing challenges and regular horror stories in the media. ${ }^{59}$ A workshop participant described her frustration at the systemic problems in the legal system in a case concerning a thirteen-year-old girl allegedly kidnapped and raped by her teacher, where lost evidence and dockets resulted in the dismissal of the case after five years. Judicial blindness to the circumstances of the poor and ignorance of the Constitution of the Republic of South Africa, 1996, particularly in the lower courts, were also cited as problems.

There are doubts within the public interest law sector about the ability of the courts to compel change by government. ${ }^{60}$ One of the participants explained that her organisation is frequently required to go to court to enforce orders given against government departments with which had not been complied. This reflects a serious problem with state capacity and respect for the courts and is a waste of the time and resources of legal organisations. She suggested that training the public and officials in rights education might be more valuable than litigation based on her experience in a rural community. Some participants confirmed the positive impact of such training while others working in a larger city were less optimistic about its efficacy given frequent staff changes. There was a concern that rights education of non-governmental organisations and state officials (such as paramedics) around protocols in violence cases might lead to public expectations of services that are often not available (such as shelters). This reflects a broader political despondency, prevalent in South Africa, regarding poor governance (including corruption) and lack of service delivery.

\footnotetext{
${ }^{58}$ Smythe (note 55 above).

${ }^{59}$ Gqola (note 27 above).

${ }^{60}$ See also Meyersfeld \& Nyembe (note 57 above) 194.
} 
Participants noted that the violence against women movement faces internal tensions, with some 'giving up' on law and preferring direct protest action while others remained convinced about the value of legal work. This challenging context suggests the need for ongoing evaluation of feminist and public interest law strategies. Using social and economic rights to address violence against women is most productive if courts are effective in holding government to account and can produce progressive decisions that generate real impacts for vulnerable individuals and communities. There may, however, be value in using the courts for other strategic ends such as to expose government violations of human rights, even where this does not lead to immediate change. It may also be valuable to expand on strategies other than or additional to litigation that draw on social and economic rights.

This discussion suggests that public interest law organisations fail to draw links between violence against women and social and economic rights where feminist arguments are not well developed or argued, or where organisations are not open to such arguments. This can occur because feminists within these organisations lack capacity or because organisational cultures are hostile to such arguments. This lack of openness can extend to communities from which claims emerge and to courts that hear social and economic rights cases. The approach to formulating legal strategies may also be a contributing factor where the lack of a gender lens - and more specifically a violence lens - can hamper a deep and intersectional understanding of inequality in relation to social and economic rights violations. Categorical thinking can also limit creative legal strategies and collaboration where lawyers remain attached to areas of specialisation. Lastly, the challenging context of poverty and epidemic violence against women and the poor implementation of legislation and court orders have led people 
within the movement to end this violence to question the capacity of law, the state and the courts to achieve change. ${ }^{61}$

\section{Social and economic rights and violence against women - suggested approaches}

The article now looks at some suggested approaches to achieve a fuller use of social and economic rights to address violence against women. This approach simultaneously responds to the challenges discussed above and draws on some of the positive examples being developed in the public interest law sector (reported on by workshop participants) that connect these issues. This discussion is situated within the literature on public interest law in South Africa. ${ }^{62}$ Although it is a relatively recent and limited body of literature, some significant ideas have emerged from this scholarship. Importantly, this literature recognises that public interest law is not restricted to litigation but includes a range of other strategies, including advocacy for law reform and administrative improvement, public education and advice, and training of service providers (both government and non-government). It also recognises that legal interventions are often only one part of a broader social campaign and thus lawyers need to work

${ }^{61}$ Other considerations for the failure of public interest law organisations to deepen the links between violence against women and social and economic rights might include: a concern that in the absence of jurisprudence supporting such linkages, it might be 'safer' to opt for a more traditional litigation route; that the circumstances of the affected client requires immediate response/accountability of the perpetrator rather than more systemic strategies; and that this work should be left to policy advocacy groups and social movement campaigns.

${ }^{62}$ The discussion is informed more broadly by a small literature on social and economic rights litigation. See for example M Langford (ed) Social Rights Jurisprudence: Emerging Trends in International and Comparative Law (2008); G MacNaughton \& DF Frey (eds) Economic and Social Rights in a Neoliberal World (2018). 
collaboratively with communities, advocacy organisations and sometimes government officials if their work is to have an impact. ${ }^{63}$ In relation to public interest litigation in particular, the Atlantic Philanthropies Report set out seven factors that are critical to effective litigation that is likely to achieve social change. ${ }^{64}$ The factors, aimed at ensuring that strategic litigation is well formulated, applied and followed up, include: proper organisation of clients, an overall long-term strategy, co-ordination and information sharing, appropriate timing, legal and factual research, characterisation/framing of the issues for the court (and others such as in the media), and follow-up that links to issues of remedy and the need for further litigation or other action to properly implement change. In their critical response to an earlier version of the Atlantic Philanthropies Report, Malcolm Langford and Jackie Dugard expressed doubt about the neatness of the proposed list. ${ }^{65}$ They suggested that the report viewed the TAC case as a model for effective litigation but argued that while it achieved success in requiring state provision of treatment, it was not assessed in the report in terms of its impact on 'social behaviour and, specifically whether the case has had any impact on the structural social condition of patriarchy, which underpins the extraordinarily high HIV/AIDS infection rate among women in South Africa'. ${ }^{66}$ They argued that litigation can have enabling or empowering impacts alongside material

\footnotetext{
${ }^{63}$ For a discussion of the choice between collaborative and confrontational work on women's health rights, see Gerntholtz \& MacLeod (note 8 above) 384 and J Brickhill \& M Finn 'The ethics and politics of public interest litigation' in J Brickhill (ed) Public Interest Litigation in South Africa (2018) 93.

${ }^{64}$ Budlender et al (note 50 above) 110-126.

${ }^{65}$ M Langford \& J Dugard 'Art or science? Synthesising lessons from public interest litigation and the dangers of legal determinism' (2011) 27 South African Journal on Human Rights 39. ${ }^{66}$ Ibid 55.
} 
ones, particularly when accompanied by legal mobilisation, which includes work in coalitions, media advocacy and linking legal issues to broader politics. In this scenario, legal losses may still result in political gains. Rather than suggesting a formulaic approach, Langford and Dugard proposed a more context-specific, resource-sensitive, sometimes responsive approach that is ideally rooted in broader mobilisation. ${ }^{67}$ It seems there is value in both views - public interest litigation is not always orderly and may take a variety of forms depending on the circumstances within which it develops. At the same time, the pointers articulated in the Atlantic Philanthropies Report are useful in guiding well-formulated strategies and may contribute towards their effectiveness. With this in mind, the article now suggests some strategies to address violence against women using social and economic rights that draw on established lessons from strategic litigation in South Africa but that are also specific to this challenge. These suggestions are not prescriptive and should be viewed as one contribution to the discussion of how better to use law and rights to achieve social change in this area.

\subsection{Building organisational responsiveness and capacity}

The literature on public interest litigation assumes organisational agreement on legal priorities and a common idea of what social change entails. The above discussion, drawing on the views of workshop participants, has shown that political differences within organisations may result in de-emphasising gender issues in litigation strategies. In addition, members of organisations may themselves face challenges in developing arguments for a greater focus on gender and violence against women in particular. A

\footnotetext{
${ }^{67}$ Responding to Langford \& Dugard's argument, Budlender et al (note 50 above) 111 acknowledge that successful public interest litigation cannot follow an entirely formulaic approach but stand by the value of the key steps they propose.
} 
first step in working towards effective legal strategies is to build organisational capacity and support for work on violence against women using social and economic rights. This could entail a range of measures, including reading or discussion groups for interested people, staff seminars presented by outside experts, and targeted discussions on gender within strategic planning or similar organisational forums. These discussions could also be used to re-evaluate organisational missions and strategic objectives. While it may be important for interested people, usually women, to form internal groups to build momentum on these issues within organisations, it is necessary to ensure that the ideas reach others in the organisation, so they are not just seen as a concern of the 'feminists'. Working with other organisations focusing on women's rights or gender issues will also build organisational understandings, but again it is important that these contacts are widened beyond a small group of sympathetic individuals. Women's rights organisations may also need to take targeted measures aimed at building their own capacity to work on social and economic rights strategies, also perhaps by working with specialist lawyers from elsewhere. This preparatory work is aimed at building what a participant described as 'a pro-poor feminist approach to litigation' and that is conscious in particular of the close relationship between poverty, gender and violence against women. Deepening and developing a critical understanding of the relationship between rights to equality and bodily integrity and social and economic rights will assist in foregrounding the intersections of these through this more conscious lens.

\subsection{Identifying cases/issues}

Organisational capacity is directly enhanced through public interest law work itself. Organisational staff will come to a greater understanding of the relationship between poverty and violence when they start recognising, more consciously, how it has an impact on their clients and the communities they seek to serve. This awareness needs to 
be built into the way in which cases and legal projects are developed. Organisations identify projects based on their broad mission. Where tackling violence against women is understood to be part of this mission, members of organisations will be better placed to formulate strategies in a more targeted fashion. Projects and cases emerge from client interviews, community consultations and in response to social and legal needs the organisations themselves identify. Sometimes these projects are responsive to issues that arise and may require immediate action, while in other cases they can be developed more slowly and systematically. In either situation, an understanding of the relationship between violence against women and social need should be built into the early stages of planning a legal strategy. Client interviews could cover a checklist of issues, regardless of the problem being canvassed, which could include violence against women. ${ }^{68}$ Interviews would need to be conducted carefully and sensitively by exploring some of the background factors leading to the problem the client presents. For example, where a person is facing eviction, they could be asked to talk about their family and financial circumstances and to identify factors contributing to their hardship. In this way, domestic violence might emerge as a contributor to their eviction or something that makes them especially vulnerable should the eviction occur. Similarly, where a person has been dismissed from their employment, they could be asked to talk about their overall experience of their job and the factors that may have contributed to the relationship breakdown with their employer. This might draw out issues such as sexual harassment that the client may not have thought to mention or felt ashamed to raise. Skill in interviewing to bring issues of violence to the surface should be developed in

\footnotetext{
${ }^{68}$ Similarly, clients raising issues of violence could be questioned on the socio-economic factors contributing to the harm they experienced, so that these contributors could better be understood and addressed in the formulation of and approach to their cases.
} 
organisations with training sessions run by experts. Staff should understand that recounting traumatic events could cause secondary trauma and should know when to limit questions and how to assist interviewees by directing them to appropriate services.

\subsection{Research}

Preparation of legal strategies requires thorough research that, as the Atlantic Philanthropies Report notes, is both factual and legal. ${ }^{69}$ The legal research may involve comparative and international law research and it would be worthwhile building up a database of violence against women case law and other materials shared across the public interest law sector. Legal research, whether undertaken in-house or by outside counsel, should be directed to consider the gender, violence and safety issues connected to social and economic rights. Factual socio-legal research, such as client interviewing, requires an ability to ask the right questions that encourage participants to disclose issues of violence they have encountered or fear. Again, violence should feature on a checklist when research studies are formulated, and as with interviews, training may be needed to ensure that interviewers are able to ask questions sensitively and responsibly. Violence against women should be part of the research agenda of all public interest law organisations given the scale of the problem and its centrality in preventing the enjoyment of a wide range of rights.

A gender violence/poverty lens should also inform the research analysis to draw out seemingly unconnected threads. For example, in research on social security administration tracking the obstacles facing Child Support Grant claimants, the fact that applicants had to approach the father of the child to obtain proof that he was

\footnotetext{
${ }^{69}$ Budlender et al (note 50 above) 120-1.
} 
unemployed and hence not able to support the child, raised the concern that women might be exposed to abusive men who they were avoiding. ${ }^{70}$ Findings of this sort inform law reform submissions and advocacy with government as well as the development of strategic litigation. In this example, challenging access barriers to the right to social security are tied to claims concerning equality and bodily integrity and deepen the social rights arguments.

Workshop participants noted some of the research they were involved with that is highlighting links between violence against women and inadequate state provision. One organisation identified lack of sanitation facilities in informal settlements as a key issue, in part because of the way this impacts on women and their exposure to violence. This observation emerged from a social audit of the City of Cape Town, which showed that it was failing to meet its obligations in the provision of services. ${ }^{71}$ It also mentioned related advocacy on infrastructural development of informal settlements because of evidence of police and ambulances being unable to access communities where there are no roads. The organisation's work included campaigns for street lighting, increased police presence and control of youth gangs in the schools and communities. ${ }^{72}$ All of these issues have implications for women's safety, and depending on how they are framed, could be understood as claims for service provision based on social rights that address gender inequality and violence against women.

\footnotetext{
${ }^{70}$ B Goldblatt 'Gender and social assistance in the first decade of democracy: a case study of South Africa's Child Support Grant' (2005) 32 Politikon 239, 249.

${ }^{71}$ Social Justice Coalition.

${ }^{72}$ Social Justice Coalition and Ndifuna Ukwazi.
} 
Another organisation was involved in a major rape attrition study. ${ }^{73}$ The preliminary findings showed close links to poverty and rape with approximately 60 per cent of rape victims being unemployed and ten per cent being university or school students. While this research exposes the gender/violence/poverty nexus in relation to the inadequacy of the justice system, it could be used to promote broader responses to women and girls' safety in schools and workplaces in terms of their social and economic rights. The same organisation planned future research on sexual violence at universities and the inadequate way in which institutions respond to complaints contrary to their policies. An organisation in another province was looking at ways of working with universities on their sexual violence policies following complaints from clients attacked on campuses. ${ }^{74}$ This research could be used purely to require punitive responses to sexual violence on campuses or could be developed, with social rights in mind, to address issues such as safe accommodation and transport. An organisation was studying the issue of forced sterilisation of women within the health system in Southern African countries, ${ }^{75}$ while a research group was looking at the health system as the primary place where sexual and domestic violence is reported rather than through the justice system. ${ }^{76}$ In both cases, the research could inform claims in terms of the right to health that together with other rights (such as reproductive and bodily integrity rights) could improve health system responses to violence against women.

The research being undertaken by these organisations provides positive examples of studies that expose links between violence and social and economic rights

\footnotetext{
${ }^{73}$ CALS.

${ }^{74}$ Lawyers for Human Rights (LHR).

${ }^{75}$ Socio-Economic Rights Project, Dullah Omar Institute, University of Western Cape.

${ }^{76}$ Gender Health and Justice Research Unit, University of Cape Town.
} 
intrusions. However, further work is needed to ensure that other organisational research is approached with violence against women in mind, even where studies appear unconnected with the issue. This approach may produce surprising new areas for important legal challenge.

\subsection{Choice of strategy}

A range of factors inform public interest legal strategies including: the social movements and campaigns within which they are located, the needs and wishes of individual and community litigants, and the political and legal context. Litigation, advocacy, information campaigns and other methods should emerge from carefully formulated strategies that fit within broader strategic objectives where possible. ${ }^{77}$ An organisation that is participating in a national coalition looking at the 'defunding and chronic underfunding of care work' by the state provided an example of work in an alliance. ${ }^{78}$ This project began with a focus on the post-rape crisis centres but spread to cover a range of care services, largely staffed by women who are very poorly paid. Campaigns emerging from this alliance may link issues of service provision for victims of violence to broader rights to social security, including social services and worker rights. In addition to working in alliances on issues, coordination within the legal sector is important for information sharing and strategy formulation. As noted, the issue of violence against women is a cross-cutting one that requires collaborative work at the stage of developing campaigns and cases and through their implementation. While this article has pointed to the importance of 'mainstreaming' the issue of violence against women into social and economic rights cases, this will not always be possible. In some

\footnotetext{
${ }^{77}$ Budlender et al (note 50 above) 116-8.

${ }^{78}$ LHR.
} 
cases, the use of an amicus may be appropriate to contribute a gender perspective and introduce evidence and arguments on violence against women where this is missing from the main case.

An example of this is the intervention as amicus of CALS in the case of Dladla $v$ City of Johannesburg at the Constitutional Court. ${ }^{79}$ The case concerned a group of people who were evicted and rehoused in the Ekuthuleni shelter in May 2012 following a leading housing decision of the Constitutional Court in the City of Johannesburg Metropolitan Municipality v Blue Moonlight Properties 39 (Pty) Ltd case requiring the city to provide temporary accommodation for evictees. ${ }^{80}$ The applicants challenged the conditions in the shelter that involved locking residents out from morning until 8pm and preventing men and women in families from living together within the shelter. The high court found these rules were violations of the applicants' privacy and dignity; however, the Supreme Court of Appeal found these violations to be reasonable limitations of the applicants' rights. CALS applied to join the case as amicus to raise gender issues relating to the right to housing. It argued that the shelter rules, though facially gender blind, had a disproportionately negative impact on women. One of these impacts was the exposure to the risk of violence. The amicus submissions ${ }^{81}$ referred to international law on the right to housing, where the UN Committee on Economic, Social and Cultural Rights noted the position of women and children in evictions, and that women face

${ }^{79}$ Dladla v City of Johannesburg 2018 (2) SA 327 (CC). The Legal Resources Centre represented CALS. The Centre for Child Law was also an amicus in the case. The SocioEconomic Rights Institute of South Africa represented the applicants.

${ }^{80}$ City of Johannesburg Metropolitan Municipality v Blue Moonlight Properties 39 (Pty) Ltd 2012 (2) BCLR 150 (CC).

81 CALS 'Amicus curiae's written submissions' (13 January 2017) $<$ http://serisa.org/images/20170113 Dladla CC - First Amicus Curiae Heads of Argument.pdf>. 
'particular vulnerability to acts of violence and sexual abuse when they are rendered homeless' ${ }^{82}$ The amicus submissions provided evidence of violence against women and the high rates of violence in spaces outside of the home and after dark, including in the Johannesburg area. It argued that, '[i]nadequate and insecure housing renders women vulnerable to dependency, gender-based violence and other forms of exploitation. This results in the violation of other rights, including dignity, equality and freedom and security of the person'. ${ }^{83}$

The Constitutional Court decided that the rules the shelter imposed violated the rights of the residents to dignity, freedom and security of the person, and privacy. ${ }^{84}$ While the Court did not specifically refer to the issue of violence against women in its reasoning, the outcome is positive for the residents. The amicus contribution to this case is an example of social rights litigation that considers the overlapping rights of dignity, equality, bodily integrity and housing for women. While the claims by the applicants for better conditions in the shelter were relatively modest, the case is significant in determining the requirements for temporary accommodation. Had the Court adopted the amicus' arguments, it would have been clear that women's vulnerability to violence and their safety needs should inform the responsibilities of a city when providing such accommodation. Future strategic litigation may be necessary to specify this obligation. This indicates a need, identified in the Atlantic Philanthropies Report, for follow-up work in strategic litigation. ${ }^{85}$ The Dladla decision can be built on if a broader campaign

\footnotetext{
${ }^{82}$ UN Committee on Economic, Social and Cultural Rights 'General Comment No. 4: The Right to Adequate Housing (Art. 11(1) of the Covenant)' (1991) UN Doc E/1992/23 para 10.

${ }^{83}$ Ibid 13.

${ }^{84}$ Dladla (note 79 above).

${ }^{85}$ Budlender et al (note 50 above) 122-4.
} 
is developed around the right to housing and women's safety. While the intervention may have been responsive to start with, through the identification of a gender 'gap' in the case, it could spur further research and activity that places violence against women more centrally within strategies to expand and deepen interpretations of the housing right.

Another approach that, like an amicus, is ancillary to the main litigation, involved a watching brief into the response by the Education Department towards a school principal following a case of rape of a girl by a schoolmate. ${ }^{86}$ The principal's failure to report the incident was cited as an example of official inaction in sexual violence cases in the education sector that leads to secondary trauma for survivors. By looking beyond the criminal justice system, the organisation found a way of exposing problematic institutional behaviour and adding to pressure for accountability in relation to the right to education.

Appropriate public interest law strategies may entail education, information and training rather than, or in addition to, litigation. Workshop participants mentioned a number of examples of such work that links issues of violence against women to social rights violations in the area of education. An organisation was running training workshops with school children on sexual violence and harassment following its research into the incidence of such practices by educators in schools. ${ }^{87}$ Another organisation was conducting training for teachers and for investigators within the Department of Education and the educators' body. ${ }^{88}$ The same organisation was involved in advocacy on getting health services into schools and for curriculum

\footnotetext{
${ }^{86}$ CALS.

${ }^{87}$ CALS.

${ }^{88}$ Section 27.
} 
development that would include information on sexual violence. ${ }^{89}$ An organisation was conducting training of paralegals in the Eastern Cape on the cultural practice of 'ukuthwala', which is a form of forced marriage that impacts negatively on young girls including by limiting their access to education. ${ }^{90}$ Training thus extends to government officials, members of the public and service providers. It is not clear whether the training programmes referred to social and economic rights and how effective this training was in building an understanding of the links between violence against women and their social and economic rights. It would be important to evaluate which forms of training are proving effective and how they interact with other legal strategies being advanced. Education and training by public interest organisations is an opportunity to develop awareness of social and economic rights, and to demonstrate how such rights relate to addressing violence against women.

The framing of litigation and other public interest law strategies is central to the political message that such work supports. ${ }^{91}$ The sometimes subtle connections between violence against women and social and economic rights need to be foregrounded in media strategies and other forms of campaigning that accompany legal work, just as they must be within the litigation itself.

\footnotetext{
${ }^{89}$ Section 27 have produced a handbook that includes a chapter on sexual violence in schools: $\mathrm{K}$ Paterson 'Sexual violence in schools' in F Veriava with A Thom \& T Fish Hodgson (eds) Basic Education Rights Handbook: Education Rights in South Africa (2017) 311

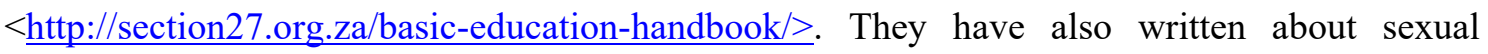
violence in social and economic spheres: Section 27 '\#Failedbysystems: Gender-based violence' (2017) < http://section27.org.za/wp-content/uploads/2017/11/GBV-Publication.pdf $>$.

${ }^{90}$ Legal Resources Centre.

${ }^{91}$ Langford \& Dugard (note 65 above).
} 


\subsection{Remedy}

Choosing appropriate remedies is critical to successful litigation. The workshop participants mentioned some examples of creative remedies being sought. In one case an organisation was representing a woman who was severely harassed on social media by boys from a prestigious school. ${ }^{92}$ The organisation asked the Equality Court to order an audit of the school's policies so as to examine (and challenge) its institutional culture, which appears to breed patriarchal attitudes. This demonstrates a thoughtful response to the issue of remedy that looks beyond addressing individual acts causing discrimination and harm towards more systemic understandings of sexism and responses to these.

An organisation was working on economic rights in a sexual harassment case against a major state-owned enterprise with reference to the freedom of trade, occupation and profession in the Constitution and was trying to ensure that gender sensitivity training policies resulted from the litigation. This too was an attempt to address systems that go beyond the individual complainant, and that set a precedent through the policy of one employer that might lead to wider change. Achieving orders for these types of remedies would suggest that litigation was successful however organisations need to monitor implementation of such orders and to take further action to ensure they result in change. ${ }^{93}$

The evidence from public interest law groups demonstrates that efforts to draw on social and economic rights on issues of violence against women are already occurring, but not always in a systematic fashion. Analysis of their activities suggests

\footnotetext{
${ }^{92}$ LHR.

${ }^{93}$ Budlender et al (note 50 above) 124-6.
} 
that greater coordination and strategic discussion both within the violence sector and the social rights sector would be valuable. The combination of grassroots consultation and grounded research would provide better evidence of the needs of poor women facing safety concerns. Feminists within social movements should deepen their capacity to formulate gendered arguments in social and economic rights cases and campaigns. The Indian sanitation case ${ }^{94}$ points to the importance of political action alongside coordinated strategic litigation that is supported by effective research and rights-based arguments. The suggestions for improved use of social and economic rights to address violence against women are just one of the means to tackle the relationship between violence and poverty through the law. Other areas of law such as family, succession, consumer and property law are fertile areas for challenge and development, in line with constitutional rights, to this end. As with social and economic rights, where organisations commit to building work on violence against women into their overall practice as suggested above, creative new approaches are likely to emerge.

\section{Areas for further enquiry}

The strategies followed by public interest groups offer a number of lessons both for South Africa and other jurisdictions and suggests the need for further inquiry.

(1) Comparative research and international information sharing would be beneficial to assist public interest lawyers and community activists. It could provide ideas for creative uses of social and economic rights advocacy and litigation and could strengthen a body of comparative jurisprudence in this area. International law

\footnotetext{
94 Milun Saryajani Through Editor Geetali Vinayak Mandakini v Pune Municipal Commissioner, Pune And Ors (note 1 above).
} 
can also provide a useful source of ideas ${ }^{95}$ and could be collected in a database of materials on violence against women and social and economic rights.

(2) Deepening the conceptual work on this issue would be helpful in a few respects: The relationship between social and economic rights and bodily integrity/autonomy arguments could be further developed. ${ }^{96}$ While the relationship between equality and social and economic rights has been more fully explored, ${ }^{97}$ as has the relationship between dignity and social and economic rights, ${ }^{98}$ the specific considerations relating to violence against women would benefit from further exploration. It is important to think about the gender dimensions of all social and economic rights in asking how these rights might apply differently to men and women. It is also critical to go further by giving specific attention to the issues of gender-based violence in developing social and economic rights that are responsive to this harm. This involves considering the sometimes-subtle ways in which power and coercion impact on access to material resources and how empowering women economically, politically and socially can enhance their safety. A systematic unpacking of each

\footnotetext{
${ }^{95}$ See, for example, the work on economic rights and violence against women being developed by the International Labour Organisation: J Aeberhard-Hodges \& L McFerran 'An international Labour Organization instrument on violence against women and men at work: the Australian influence' (2017) Journal of Industrial Relations 246.

${ }^{96}$ On the right to health, and autonomy rights, see M Pieterse 'The interdependence of rights to health and autonomy in South Africa' (2008) 125 South African Law Journal 553.

${ }^{97}$ S Liebenberg \& B Goldblatt 'The interrelationship between equality and socio-economic rights under South Africa's transformative constitution' (2007) 23 South African Journal on Human Rights 335; Fredman (note 9 above).

${ }^{98} \mathrm{~S}$ Liebenberg 'The value of human dignity in interpreting socio-economic rights' (2005) 21 South African Journal on Human Rights 1.
} 
constitutional social and economic right in relation to violence against women could produce a more comprehensive framework for a public interest law agenda. Further thought should be given to focusing on less traditional areas of law such as tax as they intersect with social and economic rights. In addition, the horizontal application of social and economic rights in relation to violence against women should be explored as should the transnational dimensions, particularly as they relate to employment but also to other impacts of non-state activity on women's safety.

(3) Some of the remedies being claimed by public interest groups discussed in this article point to the possibilities of creative and far reaching approaches to litigation. Greater thought should be given to constitutional remedies that might involve women's groups in monitoring state delivery and ensuring that court orders produce appropriate and effective outcomes.

(4) As there is so little jurisprudence on this issue, it is difficult to evaluate its impact, both in terms of actual distributive outcomes and political gains. It will be important, over time, to assess whether courts deepen their understanding of violence against women as they intersect with social and economic rights and whether they take progressive positions on these issues or protective approaches that reinforce gender stereotypes. An assessment of whether social and economic rights litigation produces 'transformative' jurisprudence should consider whether the systemic causes of violence are unearthed and tackled or whether such litigation diverts attention from more critical forms of engagement. It will also be necessary to see if governments comply with court decisions, whether and how their orders are implemented, and the impact of these. As violence against women is a thoroughly multi-causal problem, it will be 
challenging to evaluate whether courts have any impact in reducing it. Sophisticated and appropriate evaluative methodologies will be needed to measure the impact of social and economic rights cases and campaigns on the prevalence and nature of violence against women. ${ }^{99}$ Training programmes should also be carefully evaluated to ensure that they are achieving positive outcomes.

\section{Conclusion}

The challenge of addressing violence against women faces every country in the world. This complex problem requires a range of solutions with law and rights contributing just one part of these. A focus on prevention of this violence by tackling the material challenges facing women in poverty should engage the use of social and economic rights more effectively. The South African case points to the difficulties of shifting the focus of public interest law groups away from criminal justice responses to violence against women. The reasons for this include unsympathetic organisational cultures, lack of capacity and resource limitations, categorical thinking and legal silos, and some despondency with the ability of law to make headway on the problem of violence. This study shows, however, that there is a range of creative approaches that use social and economic rights to overcome economic vulnerability in creating safer communities for women and girls.

The article has made suggestions for improved strategic responses that aim to assist public interest lawyers, activists and researchers working on issues of violence

${ }^{99}$ On measuring the impact of human rights on violence against women see SE Merry The Seductions of Quantification: Measuring Human Rights, Gender Violence, and Sex Trafficking (2016). 
against women. These include building organisational commitment to and understanding of the issues relating to violence against women and its links to poverty. They also involve the inclusion of a gender, violence and poverty focus into the processes of developing legal projects and strategies. This applies to client interviews, community consultation, and work within and together with social movements and requires grounded research that unearths experiences of violence facing women in communities. At the same time, organisations working on violence against women should routinely consider the range of social and economic rights that may be used to deepen their impact and confront the poverty and disadvantage that contributes to this violence. Suggestions have also been made here for the formulation of strategies and creative remedies that unearth violence and demonstrate its links to social and economic rights violations. These include the need to strengthen collaboration between social movements/advocacy groups and public interest law organisations and researchers in developing strategic approaches that make these links. Finally, the article has suggested the need for further conceptual work, research and monitoring that would build on the existing work being undertaken in South Africa and elsewhere. A more targeted effort to use social and economic rights in the struggle to end violence against women is a project worth pursuing.

\section{Acknowledgements}

Thanks to Zeenat Sujee, Sheena Swemmer, Elsje Bonthuys, Bonita Meyersfeld and Cathi Albertyn for assistance with the development and implementation of the project on which this article is based. Thanks also to the participants of the CALS/University of the Witwatersrand School of Law workshop held on 19 June 2017 for their valuable contributions. I am grateful for helpful feedback from the anonymous reviewers and the SAJHR editor. 


\section{Conflict of interest}

No conflict of interest was reported by the author. 